Bijdragen tot de Dierkunde, 55 (2): 219-232 - 1985

\title{
OBSERVATIONS ON THE BEHAVIOUR OF THE SCARLET IBIS, EUDOCIMUS RUBER, IN ARTIS ZOO, AMSTERDAM
}

\author{
by \\ R. E. SPIL, M. W. VAN WALSTIJN \& H. ALBRECHT \\ Royal Zoological Society "Natura Artis Magistra", \\ Plantage Kerklaan 38, 1018 CZ Amsterdam, The Netherlands \\ 8 \\ Department of Animal Behaviour, University of Amsterdam, The Netherlands
}

\begin{abstract}
The Scarlet Ibis, Eudocimus ruber (Linnaeus), fam. Threskiornithidae, is the closest relative of the White Ibis, Eudocimus albus (Linnaeus). The two species live in adjoining geographical areas. Nothing is known about the Scarlet Ibis's breeding biology in the wild and only little about its breeding biology in captivity. A better understanding of the breeding of this species in captivity should help to improve its management and also to elucidate its relationship with its much better known counterpart, the White Ibis.
\end{abstract}

Three types of display behaviour are recognized in courtship: the snap display, the dipping snap display and twig pulling. The latter occurs also in greeting ceremonies, together with the up-down display, and as a precopulatory activity. Breeding pairs are stable for one breeding cycle, but occasionally promiscuous matings can be observed. Of 16 birds breeding in 1982, 12 bred again in 1983, all with a different partner.

Egg laying is preceded by a period of increasing appearance of both members of the couple together on the nest, where copulation takes place. Nests contain 2-3 eggs, which are incubated for 21-23 days. Hatching is indicated by a sudden decrease in incubation. Hatching failure can be succeeded by the laying of replacement clutches. Nesting failures were due to destruction of nests or young, often resulting from disturbances by humans or domestic cats. One pair incubated for over 4 months without apparent interruption, probably without eggs being present for most of the time.

Females spend more time incubating than males. Nest reliefs occur at a much higher rate (ca. 1 per hour) than in the wild (ca. 2 per day). For up to 3 weeks after hatching, one parent bird stays at the nest almost continuously. Unattended nests are quickly visited by other birds, predominantly males. One parent, mostly the male, almost immediately chases an intruder away. Slight variations in breeding behaviour could not be correlated with breeding success.

A dominance hierarchy could be distinguished between adult birds. Aggressive encounters consisted of three different behaviour patterns: fighting, forward threat and stab-and-counter stab. Often one bird gave way to another without overt signs of aggression. The hierarchy was not linear but could be subdivided into three groupings. The status of a bird was sex-dependent, correlated with weight and length of the bill, but not with nest-ownership or age.

The breeding behaviour of the Scarlet Ibis and the White Ibis seems to be so similar that, bearing in mind their similarity in morphology, the question may be posed whether they are conspecific.

\section{ZUSAMMENFASSUNG}

Der Rote Sichler, Eudocimus ruber (Linnaeus), Fam. Threskiornithidae, ist der vikariierende nächste Verwandte des Weißen Sichlers, Eudocimus albus (Linnaeus). Von der Brutbiologie des Roten Sichlers ist aus Freiland und Gefangenschaft nur wenig bekannt. Ein besseres Verständnis dieser empfindlichen Art soll dazu beitragen, sie besser zu schützen und die Beziehungen zum Weißen Sichler zu klären.

Bei der Balz können drei Verhaltensweisen unterschieden werden: Schnabelschnappen, Beugeschnappen und Zweigschütteln. Letzteres ist auch beim Begrüßen und, zusammen mit dem Ab-auf, beim Paarungsvorspiel zu beobachten. Während eines Brutzyklus sind Männchen und Weibchen fest verpaart, gelegentlich konnten Fremdpaarungen beobachtet werden. Von 16 Vögeln, die in 1982 verpaart waren, wählten alle Brutvögel in 1983 (12 Vögel) einen neuen Partner.

Vor dem Eierlegen sind die Brutpartner regelmäßig zusammen am Nest, wo auch die Paarungen stattfinden. Ein Gelege (2-3 Eier) wird 21-23 Tage bebrütet. Nach dem Schlüpfen werden die Jungen zunächst gehudert. Streunende Katzen oder auch menschliche Störungen können den Brutprozeß leicht stören. Mißlingt ein Gelege, wird oft sogleich mit einem folgenden begonnen. Ein Paar brütete über 4 Monate ohne Unterbrechung, vermutlich sogar ohne Eier.

Weibchen brüten mehr als Männchen. Brutablösungen treten in Gefangenschaft viel öfter auf (ca. 1 pro Stunde) als im Freiland (ca. 2 pro Tag). Bis etwa 3 Wochen nach dem Schlüpfen ist ein Elternteil beinahe konstant am Nest. Unbewachte Nester werden schnell durch fremde Vögel (meist Männchen) besucht. Diese werden sogleich verjagt, meist vom Männchen. Aus dem Verhalten eines festen 


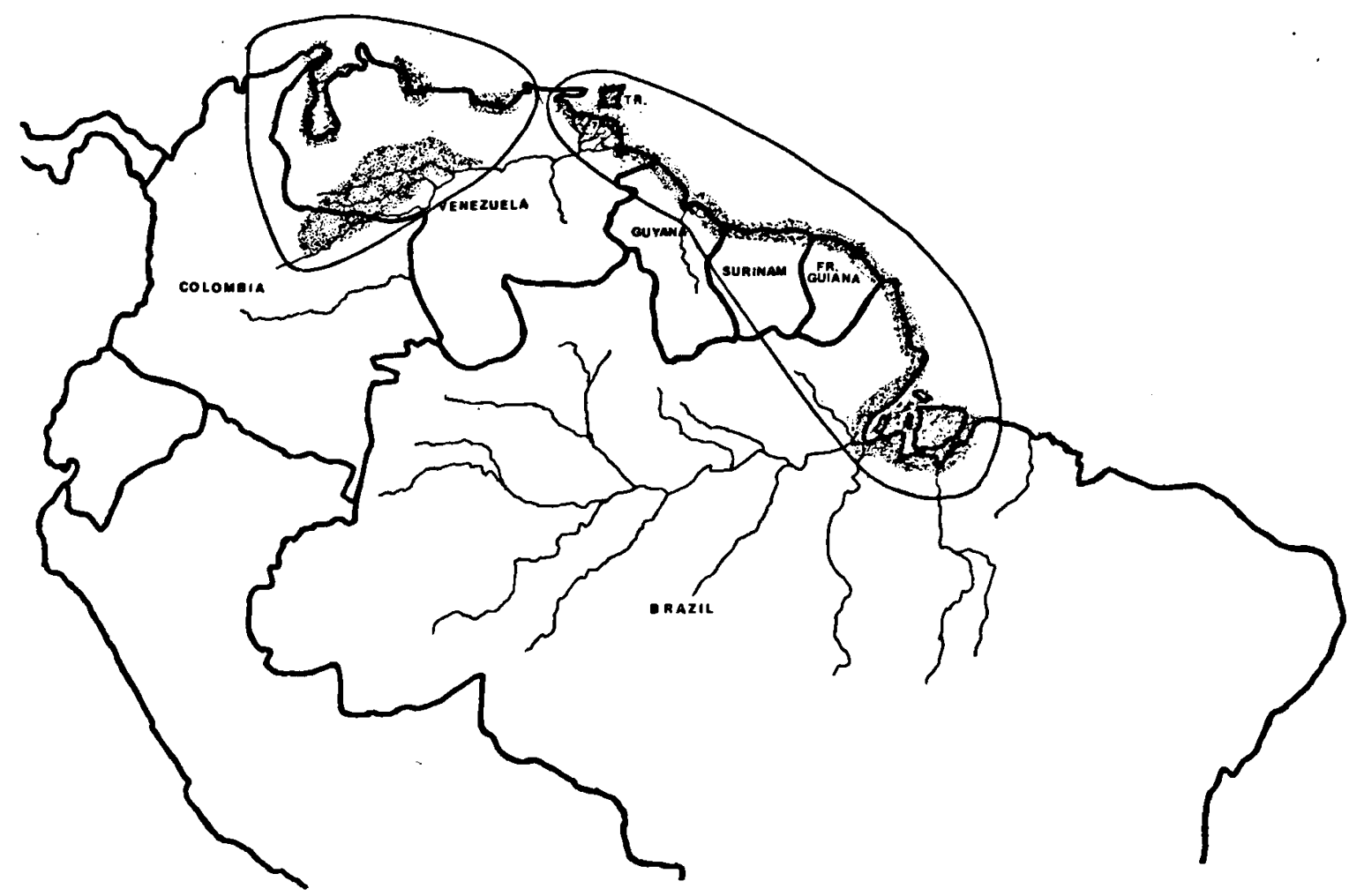

Fig. 1. Distribution of the Scarlet Ibis in South America (courtesy of Ch. Luthin). Its northwestern counterpart, the White Ibis, overlaps this range only near the border of Colombia and Venezuela (Luthin, pers. comm.).

Brutpaares ließen sich keine Rückschlüße ziehen, ob sein Bruterfolg gut oder schlecht sein würde.

Adulte Vögel lassen eine Rangordnung erkennen. Bei agonistischen Begegnungen lassen sich drei Verhaltensweisen unterscheiden: Kämpfen, Drohen und Schnabelfechten. Oft gibt ein Vogel seine Über- oder Unterlegenheit nur durch Verdrängen oder Ausweichen zu erkennen. Die Hierarchie ist nicht strikt lineär. Drei Ranggruppen konnten unterschieden werden, innerhalb deren sich auch Dreiecksverhältnisse oder andere komplizierte Beziehungen erkennen ließen. Der Rang eines Vogels hängt ab von Geschlecht, Gewicht und Schnabellänge, jedoch nicht von Alter oder Nestbesitz.

Das Brutverhalten des Roten und Weißen Sichlers zeigt so viele Übereinstimmungen, daß die Frage berechtigt ist, ob wir es mit zwei Arten oder nur mit einer Art zu tun haben.

\section{INTRODUCTION}

The Scarlet Ibis, Eudocimus ruber (Linnaeus, 1766), is one of the most strikingly coloured members of the family Threskiornithidae. Its geographical distribution is restricted to mangrove swamps and inundated plains in the northern part of South America (fig. 1). The birds live in large colonies, often mixed with other members of the order Ciconiiformes (herons, spoonbills). The number of Scarlet Ibises is decreasing rapidly, as the birds are very sensitive to human disturbance and limited in their choice of habitat (ffrench \& Haverschmidt, 1970; Spaans, 1982). In French Guiana, intensive hunting takes place for the feathers which are then used in imitation flowers (Betlem \& De Jong, 1983).

Little behavioural research has been done on the Scarlet Ibis. Some behaviour in the field has been described by ffrench \& Haverschmidt (1970); Risdon (1969) and De Tarzo Zuquim Antas (1979) mention some breeding records in zoos. The White Ibis, Eudocimus albus (Linnaeus, 1766), has been the subject of extensive ecological and ethological research by Kushlan 


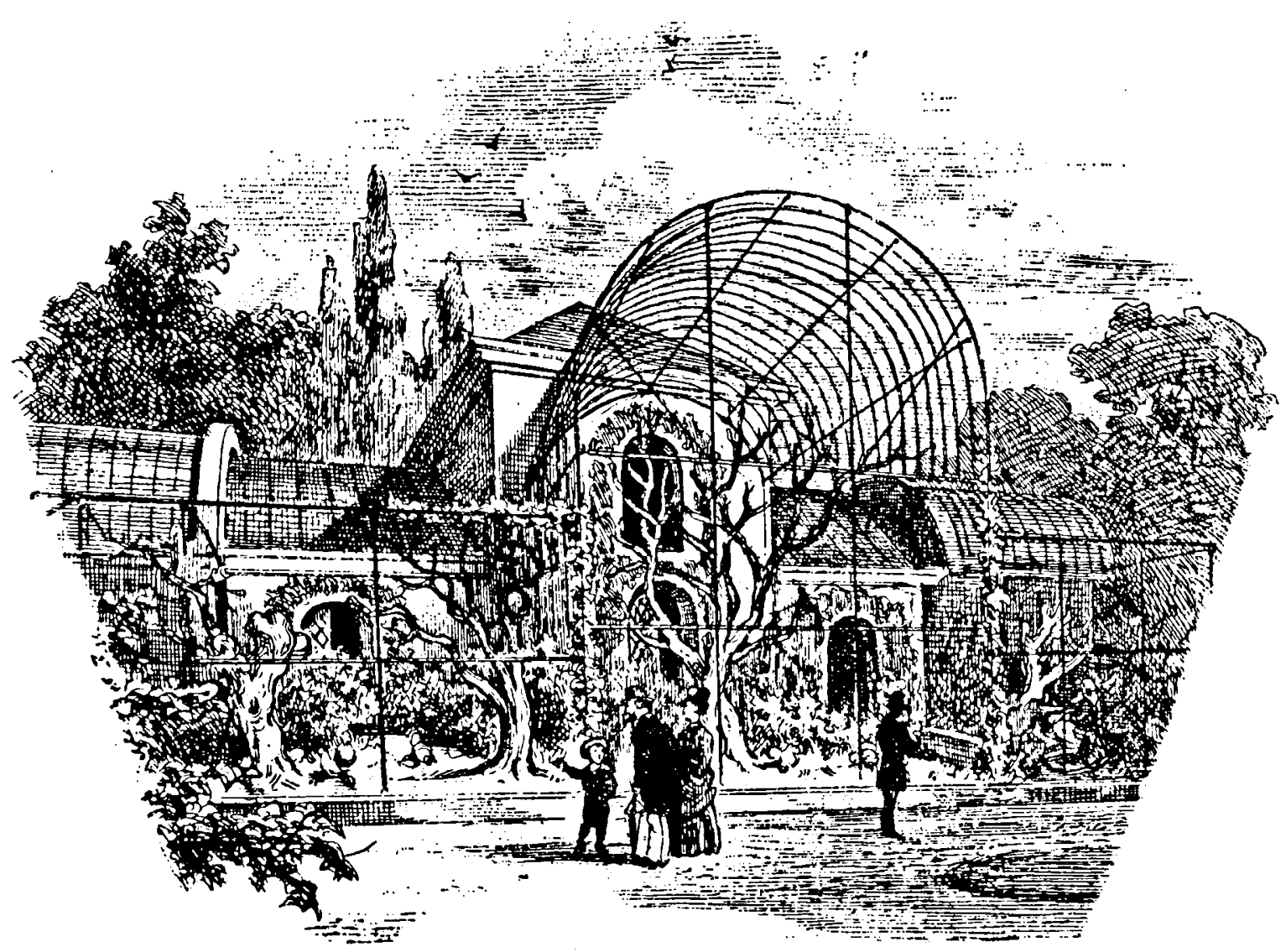

Fig. 2. The old aviary in Artis Zoo, built in 1863-1866 (cf. Anon., 1867). Reproduced from an engraving after a drawing by W. Hekking Jr., published ca. 1868 in "Geillustreerde medaille van Natura Artis Magistra te Amsterdam". A nearly identical lithograph, drawn by the same artist, has been published in the yearbook of the Royal Zoological Society "Natura Artis Magistra" for the year 1869. Nowadays, the round cage in the middle is the summer residence of the Scarlet Ibises.

(1973, 1976, 1977 and 1978) and Rudegeair (1975).

Cross breeding between Scarlet and White Ibises has occurred in Florida, where the Scarlet Ibis was introduced in 1961 (Zahl, 1967) and in the northern part of South America where the distribution range of Scarlet and White Ibis overlaps slightly (Ramo \& Busto, 1982; Luthin, pers. comm.).

The present study has been carried out in the Artis Zoo under the auspices of the University of Amsterdam and the Royal Zoological Society "Natura Artis Magistra", Amsterdam. Observations were concentrated on breeding behaviour and social interactions. Breeding records from some other zoos have also been taken into account.

\section{THE COLONY IN ARTIS ZOO}

The Scarlet Ibis has been kept in Artis Zoo since 1916 in separate summer and winter quarters. The summer residence is a cage of approximately $4 \frac{1}{2} \times 6 \times 7 \mathrm{~m}$ (fig. 2 ). The back of the cage is a brick wall covered with ivy. Seven prefabricated nests are placed in the ivy at heights varying from $2.5-5 \mathrm{~m}$ (fig. 3). More loose nesting material is added on the ground. The cage contains several branches, some 


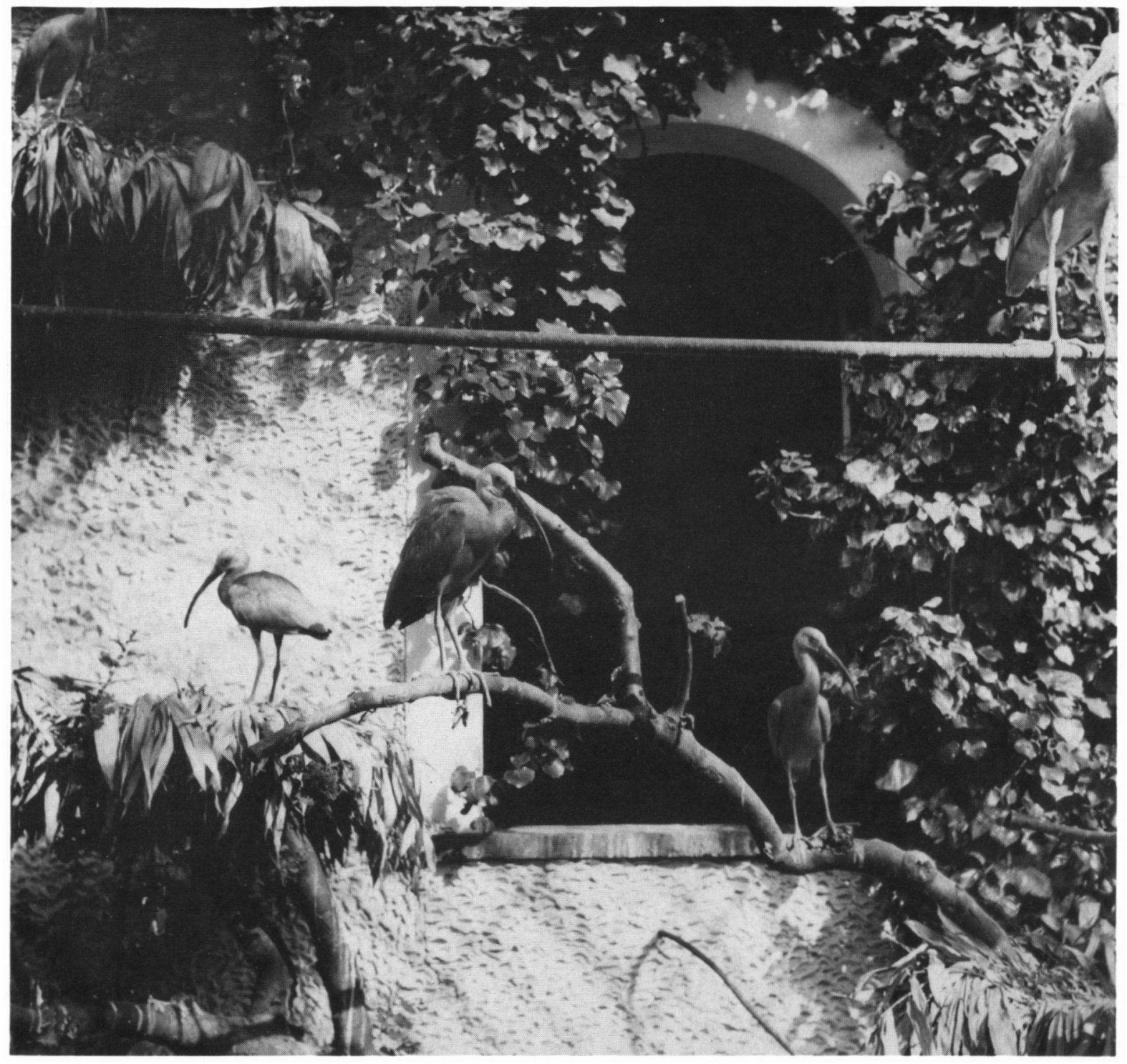

Fig. 3. Ibises with artificial nest platforms, which they sometimes build up $30-40 \mathrm{~cm}$ high (photo: Artis Zoo, A. F. Nord. heim).

bushes and a small pond. From our observation point it was not possible to look into the nests. In May 1983 the group consisted of 27 birds. The ibises varied in age from 1 to 20 years. Three birds died during the breeding season, probably as a result of disturbance caused by domestic cats. Two birds suffered from a broken bill from some earlier mishap. They, and 12 others, did not participate in the breeding process. Fledging success during the last 6 years has varied from 2-9 young (mean 4.7). The birds can be recognized individually by coloured rings worn on both legs.

\section{METHODS OF OBSERVATION}

On April 26th, 1983, the birds were transferred from their winter quarters, where no observations could be made, to the summer aviary. 
From 28 April up to 31 August 1983 we made 30 minutes observations, spread throughout the day, totalling 134.5 hours. Initial observations had been made in the summer of 1982 .

For all birds on nests three types of behaviour were recorded: standing, incubating or relieving partner. Incubating birds were identified by recording the ringing combination of the partner off duty elsewhere in the aviary. Each brood relief was scored for duration and variety of behaviour.

Besides activities at the nest, we also followed agonistic encounters, foraging and resting. Apart from these quantitative observations, qualitative descriptions were made of behaviour patterns such as courtship, copulation and greeting.

For data analysis we used, where appropriate, the Mann-Whitney $U$ test (MWU), the sign test, the $\chi^{2}$ test $\left(\chi^{2}\right)$ and the Spearman Rank Correlation Coefficient (SRCG) at a significance level of 0.05 (cf. Siegel, 1956).

\section{RESULTS}

\section{Daily activity}

Periods of increased activity were observed before 7 a.m. and after 5 p.m., when a great deal of the birds were foraging on the ground. Resting behaviour predominates between these 2 peaks (fig. 4 ).

Foraging consists of 2 different types of behaviour: eating of supplied food (at 2 p.m., mainly small fish) and probing, when the ibises walk slowly and frequently make short pecks into the ground (Kushlan, 1978). In nature, small

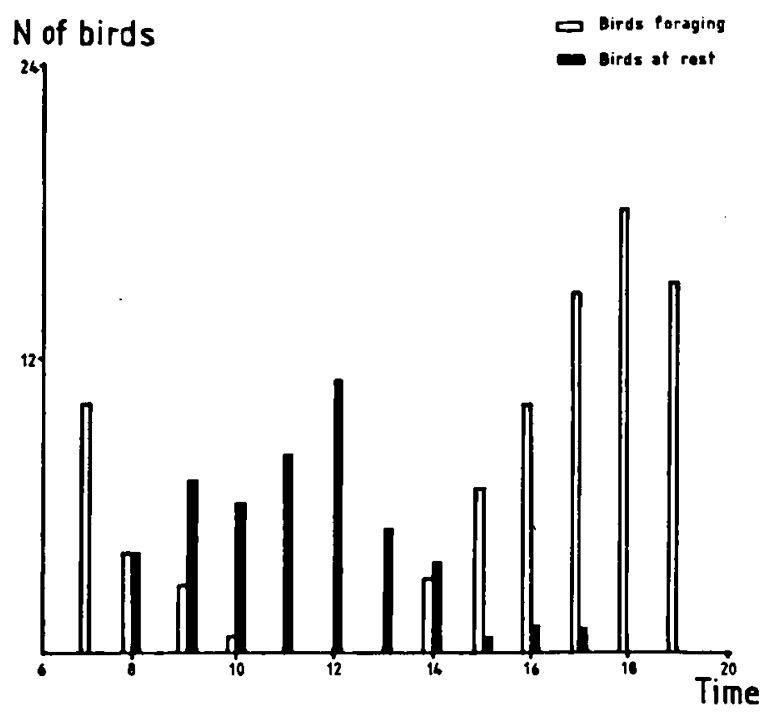

Fig. 4. The relation between time of the day and the number of birds feeding or resting.

prey items such as insects, amphibians and molluscs are taken out of shallow water or exposed mud. In the zoo this behaviour is shown even in the absence of these stimuli (in vacuo).

The foraging rhythm in nature shows a similar cycle. Early in the morning and before nightfall the ibises forage in flocks (ffrench \& Haverschmidt, 1970).

\section{Sexual dimorphism}

Scarlet Ibis show the same sexual dimorphism as described for the White Ibis by Kushlan (1977). Males of the White Ibis are heavier and have longer bills than females. For the Scarlet Ibis we inferred this correlation from copulations. From this circumstantial evidence we sexed another five birds; three birds could not be sexed this way (cf. table I).

TABLE I

Sexual dimorphism in weight (grams) and bill size (mm). S.E. = standard error.

\begin{tabular}{|c|c|c|c|c|c|c|}
\hline & \multicolumn{3}{|c|}{ Adult male } & \multicolumn{3}{|c|}{ Adult female } \\
\hline & $\bar{X} \pm$ S.E. & Range & $N$ & $\bar{X} \pm$ S.E. & Range & $N$ \\
\hline Bill size & $132 \pm 1.3$ & $104-144$ & 9 & $109 \pm 0.7$ & $98-119$ & 6 \\
\hline Weight & $959 \pm 53.5$ & $890-1060$ & 9 & $786 \pm 55.3$ & $695-840$ & 7 \\
\hline
\end{tabular}




\section{Pair formation}

The pair bond is established by mid-April when the birds are still in their winter quarters (Van Ommeren, pers. comm.). Not much courtship behaviour was observed after the birds had entered the summer residence. Five of the seven nests were occupied by established pairs on the day of release. One couple split up later and the male was seen courting another female.

Three different types of display behaviour can be distinguished in courtship:

1. The snap display (after Rudegeair, 1975, for the White Ibis). The male moves its head in a forward, slightly downward direction by stretching its neck, simultaneously making a snapping motion with the bill. The bird moves up and down, wings slightly spread.

2. The dipping snap display (Head Bobbing in Rudegeair, 1975) closely resembles the snap display, except that the snap is directed straight downward. Instead of extending the neck, the male makes a dipping motion with the neck and the head. (We chose this term because the term head bobbing does not indicate the resemblance with the snap display. Besides, Rudegeair also uses the term for another type of behaviour, i.e. for begging of the young.)

3. Twig pulling. The male closes the mandibles over a twig and moves the head to and fro, or up and down. The intensity with which the behaviour is shown varies. Twig pulling also occurs in other situations such as greeting and copulation, performed by both male and female.

The displays are frequently interrupted by preening (fig. 5), feather ruffling and inactivity and they are, seemingly, not directed against a particular individual. The displays disappear soon after a female is tolerated on the nest and becomes a partner.

When one bird approaches the partner at the nest, the latter starts greeting. This is an updown display with twig pulling. Often the arriving bird also shows twig pulling. When twig pulling jointly, the partners often cross their necks. The greeting display decreases in fre-

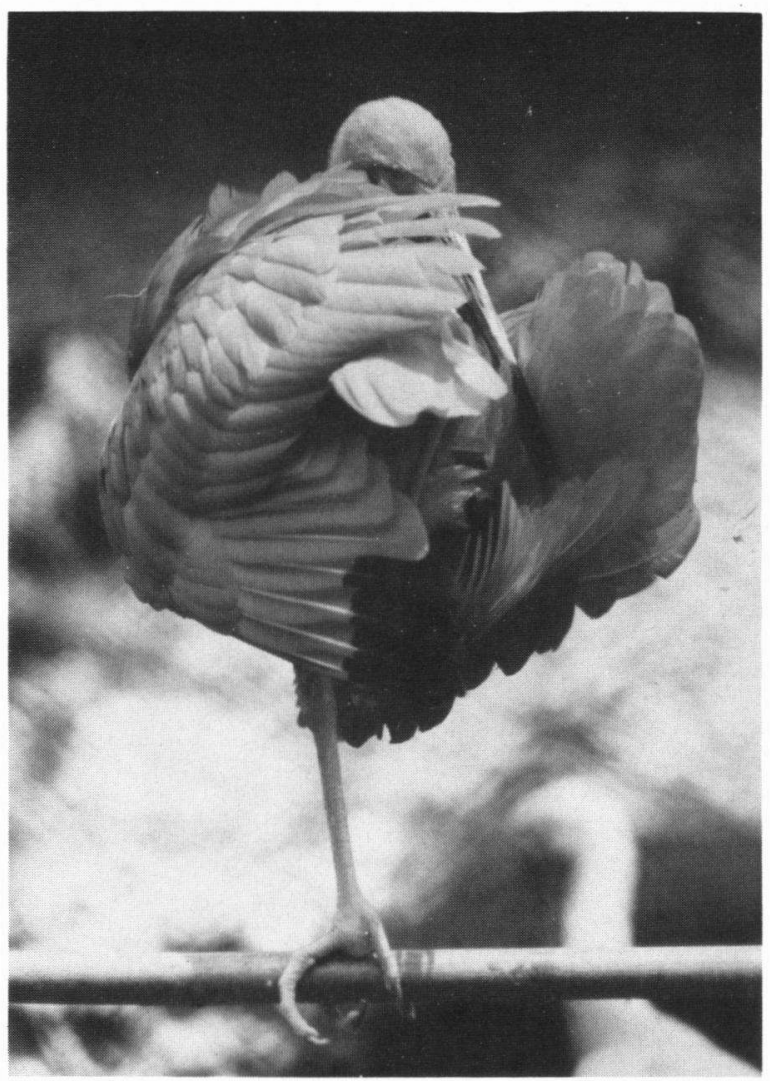

Fig. 5. Ibis preening the underpart of its wing (photo: Artis Zoo, A. F. Nordheim).

quency and intensity the longer two partners stay together.

\section{Copulation}

All copulations and copulation attempts $(N=43)$ took place on a nest. Precopulatory behaviour consists of twig pulling, with male and female standing close to each other. The male sometimes crosses his neck over the neck of the female. When the female slightly lowers her body, mounting takes place. Postcopulatory behaviour consists of preening or standing.

Copulations took place in the week prior to incubation. In this period the couple spends much time together on the nest.

\section{Collecting of nest material}

Both male and female are seen carrying twigs and leaves to the prefabricated nest-platform. 
Nest material can be scarce in the field near to a breeding colony and ibises have been seen stealing material from other nests (Rudegeair, 1975). In our group, where a surplus of nest material was offered on the ground, this pirate behaviour was also seen, being performed more by males than by females. One nest in particular, when little attended by the breeding couple, was a target of this pirate behaviour.

\section{Incubation}

In nature the Scarlet Ibis usually lays two eggs (ffrench \& Haverschmidt, 1970). Under optimal conditions, with good food availability, three eggs can be laid. Four eggs are seldom found. Eggs are laid at intervals of 2 days. Incubation for captive Scarlet Ibises lasts for 21-22 days (Risdon, 1969). In the wild an incubation period of 23 days was found (ffrench \& Haverschmidt, 1970). Based on these data, and on behavioural changes in our group, we inferred that the incubation time was about the same (21-23 days, fig. 6).

During cold days the birds were often seen incubating with their bills hidden in the dorsal feathers. When temperatures were high, the birds were seen standing over the eggs (or hatchlings), with wings spread, feathers erect and the gular pouch vibrating. This behaviour was only observed when the nest was fully exposed to the sun. When they are disturbed under such circumstances, this behaviour is not shown and an embryo can die within minutes. This probably contributed to the low hatching success. The behaviour resembles sunbathing behaviour (Wennrich, 1982) which is shown off the nest.

Both sexes take part in incubation, with females spending more time on it in the morning (MWU, $p=0.001$ ) and males in the afternoon (MWU, $p=0.032$ ). The overall presence on the nest did not differ significantly for both sexes (MWU, $p=0.12$ ). However, in successful couples the females spent significantly more time on the nest (MWU, $p=0.029$ ).

No significant difference in time spent incubating could be found between successful and unsuccessful couples $\left(\chi^{2}=2.04\right)$. Hatching success was not correlated with the age of a breeding bird.

In nature, birds leave for the foraging grounds when they are not incubating. As a result of the long distance to the nest, brood reliefs take place 2-3 times a day only (ffrench \& Haverschmidt, 1970; Rudegeair, 1975) and always within 30 seconds. In the Amsterdam captive flock, we found a much higher relief frequency, varying between 0.75 and 1.25 per hour. Observations in "Het Noorder Dierenpark" at Emmen (The Netherlands) and in "Vogelpark Walsrode"' (F.R.G.) indicate that this frequency is not uncommon in captive birds. Brood reliefs did not take place as smoothly as Rudegeair states for the situation in the wild. They were very variable in length and could last up to 5 minutes. No difference was found between successful and unsuccessful birds in relief frequency (MWU, $p=0.285$ ) and relief duration (MWU, $p=0.107$ ). Relief frequency and duration were not strongly correlated (SRCC, $\left.r_{s}=+0.41\right)$.

Often the incubating bird did not rise immediately after its partner had arrived. The latter then showed different types of behaviour. The bird began by walking around its incubating partner and then showed twig pulling near the partner's head (fig. 7). If still no reaction was forthcoming, the bird approached its partner even closer and put one leg on its back. This always made the incubating bird stand up and leave, or the birds would circle around each other (fig. 8) after which either of the partners left. No correlation was found between quick relievers and breeding success.

\section{The young}

Although nests containing three young are not uncommon in the wild, all three young seldom survive (ffrench \& Haverschmidt, 1970). The major reason seems to be competition for space. In Artis Zoo there were seven breeding couples. Three couples raised one young, one couple raised two. 

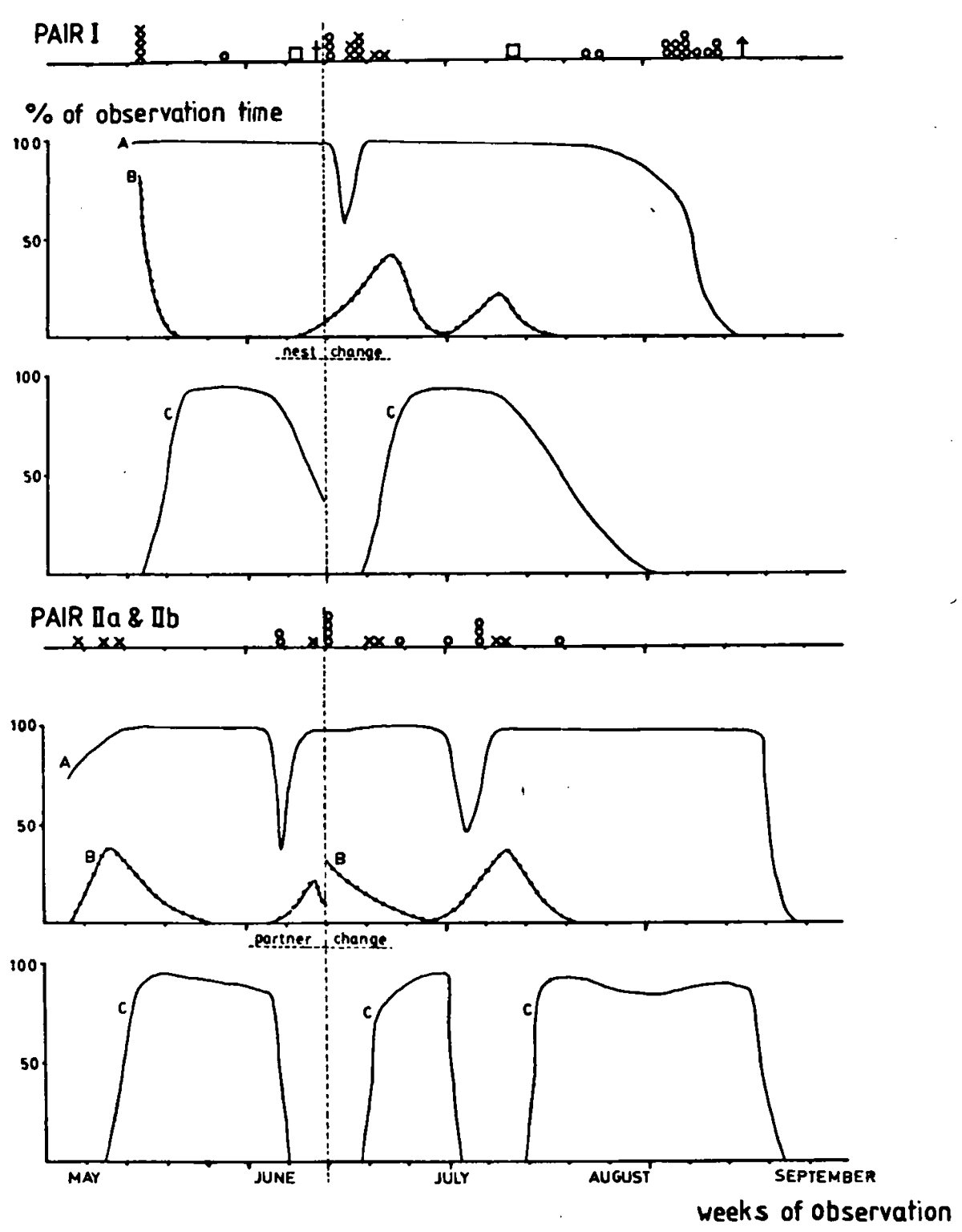

Fig. 6. Nest activities of two pairs in the breeding season 1983. Pair I changed nest site in June. The male of pair II changed his partner in June. $A=$ presence of at least one nestowner at the nest; $B=$ presence of the two nestowners together at the nest; $\mathrm{C}=$ incubation by the nestowners; $\mathrm{o}=$ expulsion by one nestowner; $\mathrm{X}=$ copulation or copulation attempt; $\square=$ chick heard or seen; $\uparrow=$ chick found dead; $\uparrow=$ chick left nest.

The hatchlings were invisible until they were old enough to raise their heads (2-3 days old). They are covered in black down. The bill is pink-white with a black tip, measures approximately $2 \mathrm{~cm}$ and is not yet curved. The ventral part of the body turns greyish after 1 week, the legs remaining black. The bill turns black, except for a small band at the base, which remains white.

After 10 days, the first contour feathers appear. By this time the nestling starts exploring the surrounding branches, using claws, wings 


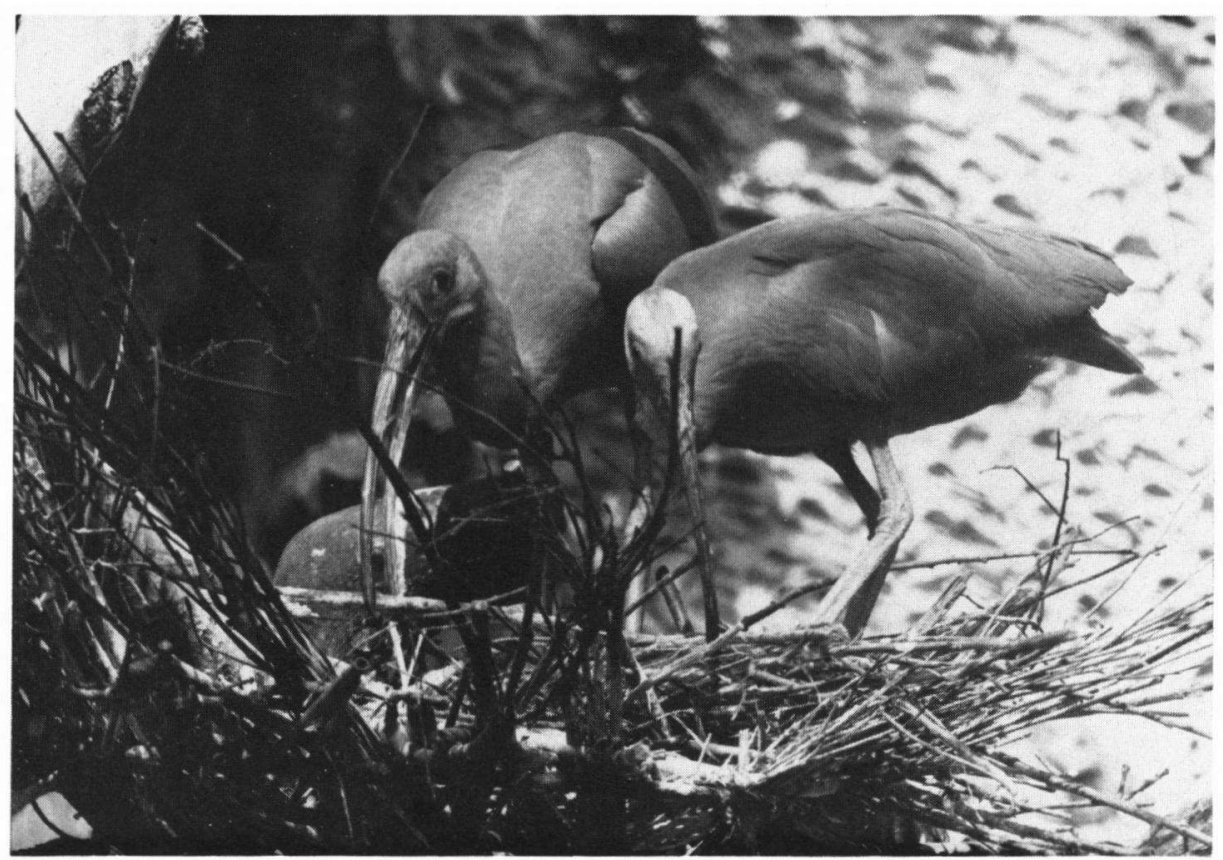

Fig. 7. The male on the left is trying to induce his partner to leave the nest (photo: Artis Zoo, A. F. Nordheim).

and bill for climbing, but always returns to the nest. From this age onwards it is left alone more and more by the parents.

When a visiting bird lands on the nest, the nestling sometimes begs for food, but later on crouches and keeps silent. When confronted with begging, a visitor reacts aggressively, pecking the nestling on the head. Crouched young are left unharmed. Screaming of the young alarms one or both parents and the male immediately chases the intruder away. The visitor is usually an unmated bird, male or female. Yearlings also show great interest in the nestlings. One of the visitors was often seen preening the chicks of one nest. This is the only case of allopreening in the Scarlet Ibis that we observed. In the White Ibis it seems to be of more regular occurrence (Rudegeair, 1975).

After 4-5 weeks the young fledge, being able to fly short distances. None of the young was seen returning to the nest after this. Until well after fledging, the young are fed by the parents.

Feeding takes place by regurgitation (fig. 9) which is elicited by begging of the young. Begging consists of bobbing the head, squeaking and flapping the wings. With increasing age, the bobbing is aimed towards the parent's bill, and still later at its distal part. The squeaking turns into screaming and the wings are flapped violently. Often, when one of the parents lands on the nest it turns its head away from the chick which increases the begging even more.

Both male and female take part in caring for the offspring. Couples spend more time incubating the eggs than brooding the hatchlings, during their first week (MWU, $p=0.029$ ). In the first three weeks after hatching the female spent more time on the nest than the male (MWU, $p=0.029$ ). However, females do not brood more than males (MWU, $p=0.057$ ). There is no difference in relief frequency before and after hatching of the young (MWU, $p=0.1$ ).

\section{Visiting behaviour}

Often a bird was observed visiting a nest $(N=49)$ which had already been occupied by a pair, but was deserted for a few minutes. This visiting was done by males or females with or 


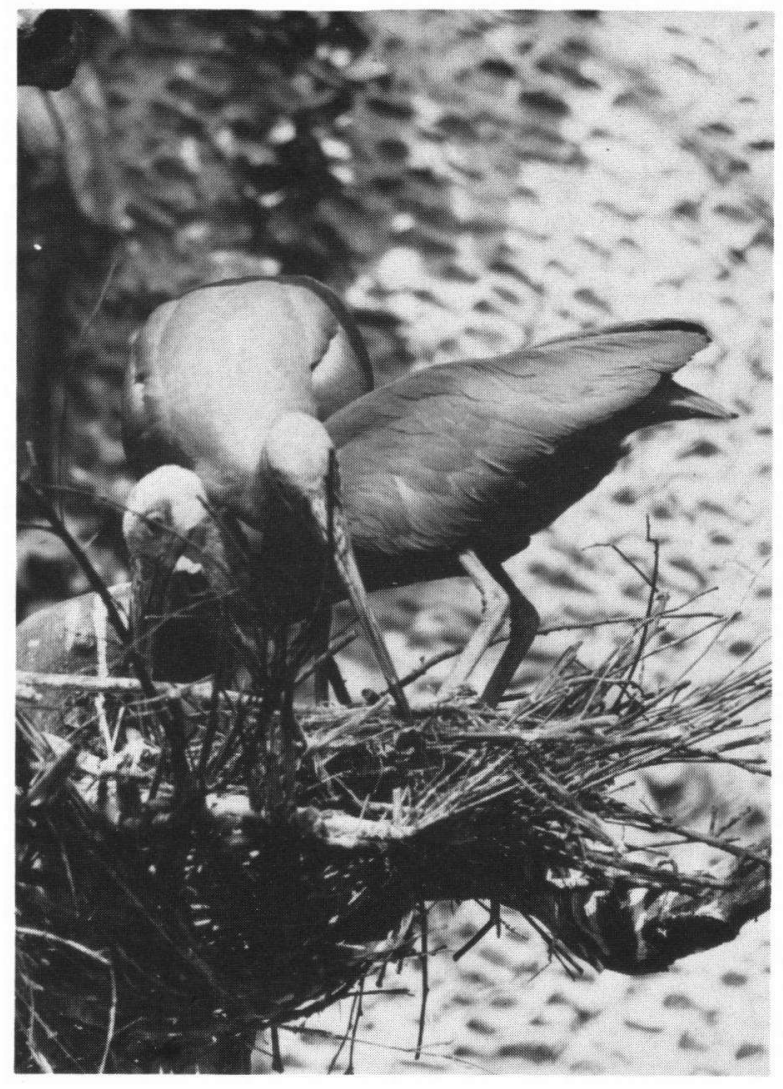

Fig. 8. The male crosses his neck over his partner. The female will not leave and sit down again on the nest (photo: Artis Zoo, A. F. Nordheim).

without a nest of their own. A nestowner always chased such an intruder away. This was done significantly more frequently by males $\left(\chi^{2}\right.$ test; $p<0.05)$.

In total we observed 35 visits from males and 11 visits from females. Nestowners visited 24 times and non-nestowners 25 times. No significant differences exist between males and females in performing this behaviour, nor between nestowners and non-nestowners. Female nestowners showed this visiting behaviour more frequently than females without a nest (MWU, $p=0.05$ ).

When a pair showed a decreasing presence on the nest, either about 4 weeks after hatching, or when brood attempts had failed, many birds visited the nest. After 2 or 3 days, the original nestowners made no particular attempts to stake their claim and the nest could be considered abandoned.

\section{Dominance relationships and agonistic behaviour}

In the breeding season a colony of captive Scarlet Ibis shows a pronounced territorial aggression which can result in damaged eggs and even destroyed nests (De Tarzo Zuquim Antas, 1979). This is comparable to the White Ibis in the field (Rudegeair, 1975). Outside the colony at the foraging grounds no aggression is observed. Nestlings of the Hermit Ibis, Geronticus eremita (Linnaeus, 1758), like the White Ibis compete aggressively for food. A linear dominance hierarchy develops with the oldest chick on top (Thaler et al., 1981; Oliver et al., 1979; Rudegeair, 1975). Young of White Ibis which have left the colony form flocks in which a stable hierarchy develops for several days when access to provided food is given in a natural environment. This hierarchy appeared also to be positively correlated with size (Rudegeair, 1975).

From our observations of adult birds, we divided the agonistic behaviour into two components, viz. aggressive behaviour on the nestsite and aggressive behaviour in the open space of the enclosure.

Aggressive behaviour on the nestsite consists of expulsion of visitors by nestowners. The most common form of aggression is fighting. The nestowner quickly returns to the nest after a visitor has landed on it. He spreads his wings and frequently pecks at the neck of the intruder. Many birds have an almost bare neck at the end of the breeding season. A visitor is always driven away by the nestowner, if the visitor had not already left before the nestowner arrived.

Three different forms of aggression were distinguished in the open space of the enclosure. With increasing intensity this was the forward threat, stab-and-counterstab, and fighting (Rudegeair, 1975). In the forward threat, the body was held horizontally with the neck extended and the bill directed forward against the opponent. In stab-and-counterstab, alternative pecks are exchanged with the oppo- 


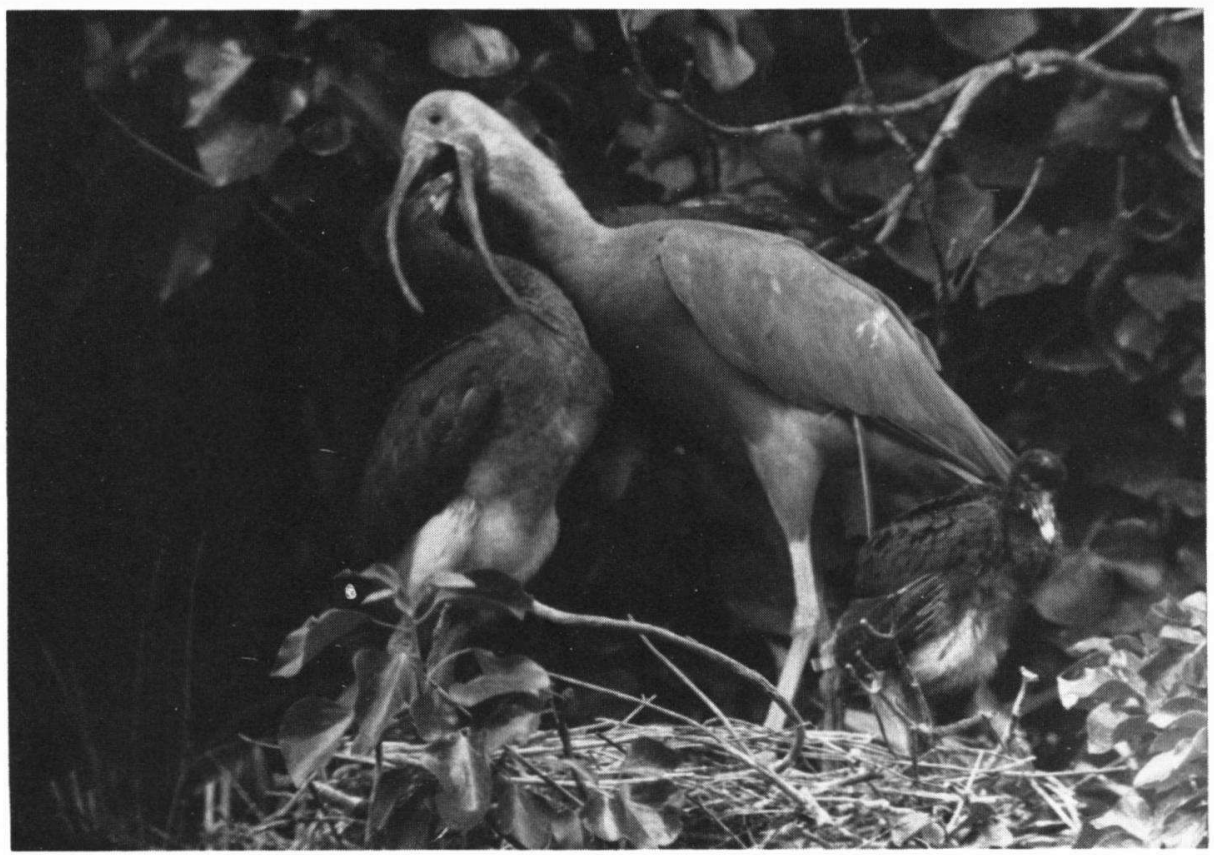

Fig. 9. A young bird picks regurgitated food from his parent (photo: Artis Zoo, A. F. Nordheim).

nent, with feathers on neck and back erected and the wings slightly spread. In fighting the bills touch each other as in the nestsite encounters. All three types of encounter could have a winner or end undecided. Frequently it also occurred that two birds confronted each other with no overt signs of aggression but with one bird fleeing.

From all aggressive confrontations in the open space of the enclosure $(N=135$ in 1982 and 334 in 1983) in which one bird gave way for another we constructed a dominance order. The birds could be divided into three groups (table II). The status of a bird is expressed by the number of confrontations won and/or lost.

Group A contains those birds which significantly drove away other birds more times than they were driven away themselves. Group B contains those birds without a significant difference in driving away or being driven away. Group C contains those birds which significantly have been driven away more than having driven away other birds (sign test, $p<0.05$, $N=27, x=7$ ). There is a significant difference between the groups $A, B$ and $C$ in driving away birds from other groups $\left(\chi^{2}\right.$ test, $\left.p<0.01\right)$. Birds from group A displace birds from their own group significantly less than birds from group B or group $\mathrm{C}\left(\chi^{2}\right.$ test, $p<0.01, p<0.02$, respectively). Birds from group $B$ displace birds from group A significantly less than birds from their own group ( $\chi^{2}$ test, $p<0.01$ ). They displace birds from group $\mathrm{C}$ significantly more than birds from their own group ( $\chi^{2}$ test, $p<0.01$ ).

TABLE II

Composition of the dominance groups in 1982 and 1983 (see also fig. 11).

\begin{tabular}{lcc}
\hline Group & 1982 & 1983 \\
\hline A & $30^{\circ} \circ$ & $3 \circ \sigma^{\circ}$ \\
B & $9 \circ \%$ & $7 \circ \%$ \\
& $4 \%$ \% & $4 \%$ \% \\
& 3 ?? & 4 ?? \\
C & $4 \%$ \% & $4 \%$ \% \\
& 2 ?? & 2 ?? \\
Total & 25 & 24 \\
\hline
\end{tabular}

The ?? indicate that during the season the sex of these birds was not known. 


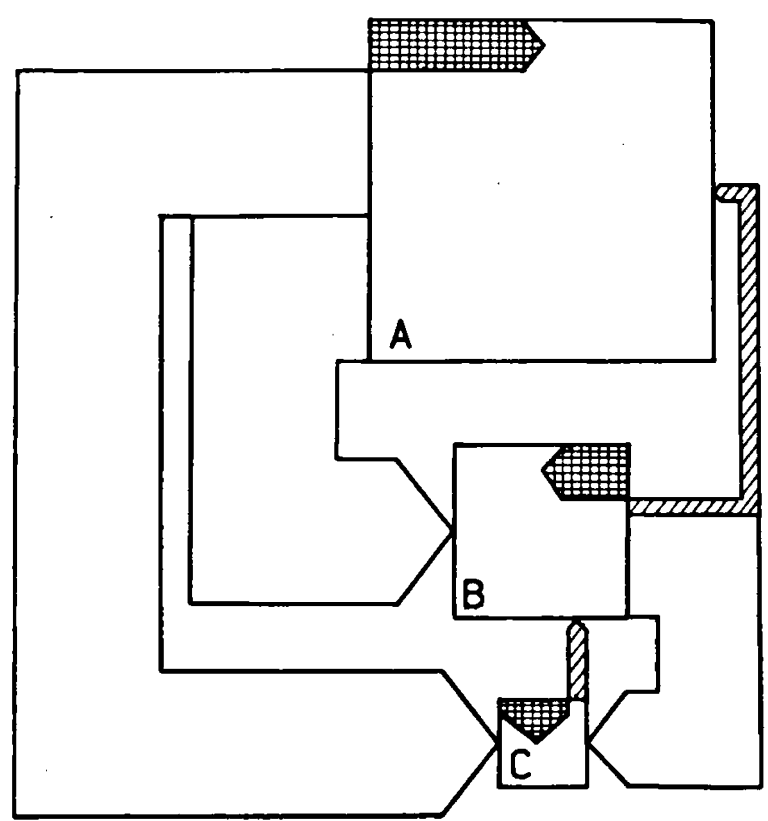

Fig. 10. Dominance based on expulsions between the members of three groups. The size of the square represents the amount of expulsions caused by each bird from that group. The arrows represent the percentage of expulsions directed to each member of the indicated group. The chequered, blanco and striped markings represent expulsions toward members of their own group, to members of a submissive group and to members of a dominant group, respectively.

Finally, birds from group $\mathrm{C}$ displace birds from the other two groups significantly less than birds from their own group ( $\chi^{2}$ test, $p<0.05$ in both cases). A bird from group A displaces other birds significantly more often than a bird from group $B\left(\chi^{2}\right.$ test, $\left.p<0.001\right)$ or from group C ( $\chi^{2}$ test, $\left.p<0.001\right)$. A bird from group B displaces birds from other groups significantly more often than a bird from group $\mathrm{C}$ does $\left(\chi^{2}\right.$ test, $p<0.001$ ). (Fig. 10.)

A linear dominance hierarchy, as described for young White Ibis, did not emerge. Reversals, triangles or other circular relationships obscured such clear relationships. Only femalefemale confrontations were unidirectional.

The dominance order in the three groups appeared to be sex-dependent. It was positively correlated with weight (SRCC, $\left.r_{s}=+0.5\right)$ and bill size (SRCC, $r_{s}=+0.65$ ). Males were significantly more dominant than females (MWU, $p<0.05$ ). The most dominant group A contained only males. The birds from group C, for which the sex could not be established, appeared to be females, according to weight and bill size measurements. Males chase others significantly more often than females did (MWU, $p<0.05$ ). The dominance order was neither correlated with having a nest (SRCC, $\left.r_{s}=+0.21\right)$, nor with age (SRCC, $\left.r_{s}=+0.06\right)$, nor with visiting behaviour (SRCC, $\left.r_{s}=+0.17\right)$. Changes of group membership within one season occurred between $A$ and $B$ and between $B$ and $C$ (fig. 11).

\section{DISCUSSION}

\section{Comparison with the natural situation}

Because of lack of data on the Scarlet Ibis in the field, we compared our data with field data on the White Ibis (Rudegeair, 1975; Kushlan, 1973, 1976, 1977, 1978). This seems justified because of their close taxonomic relationship.

The daily activity of our captive group closely matches the activity curve of the White Ibis in

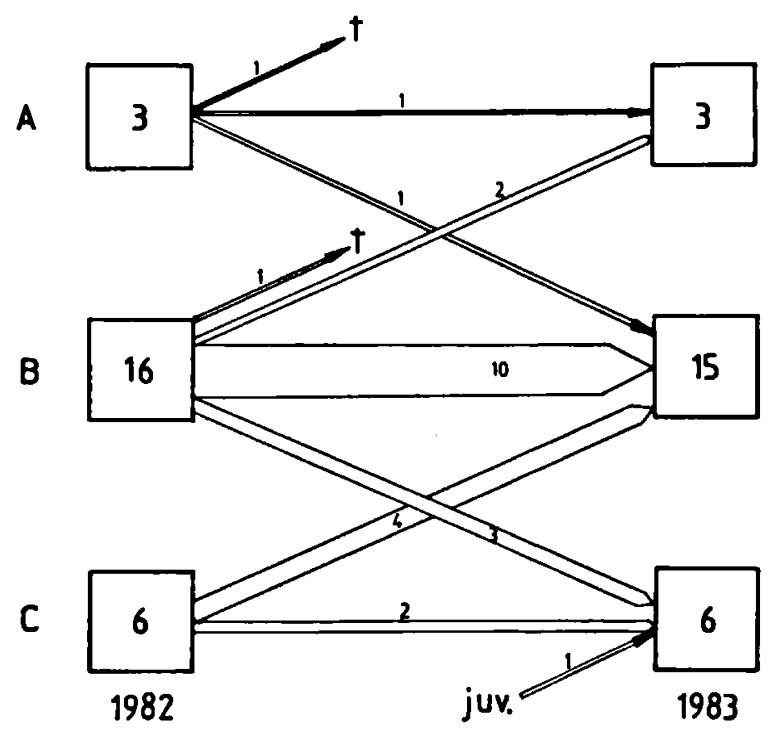

Fig. 11. Changes in dominance orders between 1982 and 1983. The numerals indicate the number of birds. Between 1982 and 1983 two birds died and one bird grew up. 
the field. In spite of food being provided at fixed hours outside their activity period, the birds forage early in the morning when no food is available. Kushlan (1976) demonstrated an endogenous rhythm for food intake in nestlings and correlated this with the foraging rhythm of the adults. Both Kushlan's and our data suggest an endogenous foraging rhythm.

Normally two brood reliefs per day are found in the field. Rudegeair (1975) states that the number of reliefs reflect the distance from the nest to the foraging grounds. He found frequencies of one per day for remote nesting colonies to three per day for adjacent nesting colonies. In our captive situation, where the distance between nest and food is minimal, a higher frequency is to be expected. A frequency of one per hour or even less seems to be detrimental to the peace at the nest. Whereas reliefs in the field always occur within 30 seconds, reliefs in our group often took several minutes, leaving the eggs exposed. However, relief frequency and duration were not correlated with hatching success in our small sample. More data and comparison with the field situation are desirable. From breeding behaviour alone it was not possible to predict the success of a breeding couple. Breeding success seemed to depend rather heavily on incidental influences.

In the White Ibis, the male chooses the nest site. This might explain the more frequent visiting behaviour shown by males. Visiting by nestowners can partly be explained by the robbing of nest material, if this pirate behaviour is integral part of Scarlet Ibis behaviour in the field. Nest material is, after all, supplied freely in our situation and is scarce in the field. However, the greatest number of nest visits cannot be contributed to pirate behaviour because during many visits no attempts were made to take nest material. Possession of a nest may be an important factor in the life of the Scarlet Ibis. This is also illustrated by the fact that several couples were "breeding" for several months on end.

The establishment of a dominance hierarchy in the Scarlet Ibis appears to be sex-dependent. Males drive away a greater number of birds more frequently than do females. The males are not selective as to males or females. The most dominant males show most of the aggression. In 1983 , one male accounted for $20 \%$ of the total number of dislodgements of other birds. No significant correlation was found between dominance and visiting behaviour and between dominance and nestownership.

The status of a bird can change over two seasons. As our method of ranking was based on observations of a whole season, we do not know if these changes have been brought about gradually.

The dominance hierarchy in the Scarlet Ibis was correlated with bill size and weight. Males have longer bills and are heavier than females. It may be supposed that the longer bill has a social function, as, according to Kushlan (1977), in the equally sexual dimorphic White Ibis, no difference with regard to feeding has been found. Further investigations with regard to the significance of this sexual dimorphism are necessary.

\section{Division of labour between sexes}

Both males and females were seen taking twigs to the nest. Rudegeair (1975) mentions that the male White Ibis collects the nest material and the female builds the nest, sometimes helped by the male. Since we observed this carrying of twigs throughout the season, we assume that this is part of nest maintenance activities which are mediated partly by the "offering of a present"'. Archibald et al. (1980) claim that this behaviour functions as a sexual stimulation of the partner. Since we observed this behaviour until well after the copulation period we suggest that it functions to set the partner at ease. Thaler et al. (1981) assign this same function to the corresponding behaviour in the Hermit Ibis, where it is shown only by males.

According to Kushlan (1976) females of the White Ibis incubate mainly at night and males during the day. Rudegeair (1975) observed that the sexes alternate on the nest every other day. Our observations demonstrate that females spend more time incubating in the morning 
than in the afternoon. In how far this is determined by captivity conditions we do not know.

\section{Comparison of the Scarlet and White Ibis}

Luthin (pers. comm.) has studied various ecological and morphological aspects of Eudocimus ruber and $E$. albus. He concludes that they are virtually the same in all respects. Comparing our data on courtship and copulation with the literature on the White Ibis, we can support his conclusion. It appears that no behavioural barriers exist to prevent hybridization, though the colour difference might prevent complete interbreeding. The possibility of physiological barriers has not yet been investigated. As we observed the Scarlet Ibis only in captivity, further behavioural studies in the field are desirable.

\section{ACKNOWLEDGEMENTS}

We would like to thank Dr. B. Heuts for his help with statistics, and Dr. B. M. Lensink, Drs. D. Dekker, J. Jansen and K. Schoelitz for making these observations possible.

\section{REFERENCES}

Anonymous, 1867. De nieuwe volières. Jaarboekje van het Koninklijk Zoölogisch Genootschap Natura Artis Magistra voor het jaar 1867: 162 (M. Westerman \& Zoon, Amsterdam).

Archibald, G. W., S. D. H. Lantis, L. R. Lantis \& I. MunetchikA, 1980. Endangered ibises Treskiornithinae: their future in the wild and in captivity. Int. Zoo. Yb., 20: 6-17.

Betlem, J. \& B. H. J. DE Jong, 1983. De rode ibis moord in Frans Guiana. Het Vogeljaar, 21 (4): 192-198.
Ffrench, R. P. F. Haverschmidt, 1970. The Scarlet Ibis in Surinam and Trinidad. Living Bird, 9: 147-165.

Kushlan, J. A., 1973. Promiscuous mating behavior in the White Ibis. Wilson Bull., 85 (3): 331-332.

$\rightarrow, 1976$. Feeding rhythm in the nestling White Ibis. Wilson Bull., 88 (4): 656-658.

-, 1977 . Sexual dimorphism in the White Ibis. Wilson Bull., 89 (1): 92-98.

- 1 1978. Feeding ecology of wading birds. Res. Rep. natn. Audubon Soc., 7: 249-297.

Oliver, W. L. R., M. M. Mallet, D. R. Singleton \& J. S. Ellet, 1979. Observations on the reproductive behaviour of a captive colony of Bare-faced Ibis Geronticus eremita. Dodo, J. Jersey Wildl. Preserv. Trust, 16: 11-35, pls. 1-8.

Ramo, C. B. Busto, 1982. Son Eudocimus ruber y E. albus distintas especies? Doñana, Acta Vertebrata, 9, 404-408.

Risdon, D. H. S., 1969. The breeding of Scarlet Ibis (Eudocimus ruber). Avicult. Mag., 75: 165-167.

Rudegeair, T. J., 1975. The reproductive behavior and ecology of the White Ibis (Eudocimus albus): 1-147 (Ph. D. Thesis, Univ. Florida).

Siegel, S., 1956. Nonparametric statistics for the behavioral sciences (international student edition): i-xvii, 1-312 (McGraw-Hill Kogakusha, Tokyo etc.).

SpaANs, A. L., 1982. De Rode Ibis: een pronkjuweel van de overstromingsvlaktes van tropisch Zuid-Amerika. Het Vogeljaar, 30: 189-193.

Tarzo Zuquim Antas, P. DE, 1979. Breeding the Scarlet Ibis Eudocimus ruber at the Rio de Janeiro Zoo. Int. Zoo Yb., 19: 135-139.

Thaler, E., E. Ettel \& S. Job, 1981. Zur Sozialstruktur des Waldrapps Geronticus eremita - Beobachtungen an der Brutkolonie des Alpenzoos Innsbruck. J. Orn., 122 (2): 109-128.

WennRich, G., 1982. Sunbathing behaviour in five species of ibises (Threskiornithidae) at the Walsrode bird park, Germany. Avicult. Mag., 88 (2): 96-100.

ZAHL, P. A., 1967. New scarlet bird in Florida skies. Natn. geogr. Mag., 132: 874-882.

First draft received: 30 March 1984

Final draft received: 25 June 1985 